\title{
Human embryonic stem cells and respect for life
}

John R Meyer San Francisco, California, USA

\begin{abstract}
The purpose of this essay is to stimulate academic discussion about the ethical justification of using human primordial stem cells for tissue transplantation, cell replacement, and gene therapy. There are intriguing alternatives to using embryos obtained from elective abortions and in vitro fertilisation to reconstitute damaged or dysfunctional human organs. These include the expansion and transplantation of latent adult progenitor cells.

(Fournal of Medical Ethics 2000;26:166-170)
\end{abstract}

Keywords: Primordial stem cell research; embryonic stem cells; pluripotent stem cells; embryo research

\section{Introduction}

The United States Department of Health and Human Services ruled that human embryonic stem (ES) cells fall outside a ban on federal funding of human embryo research. Embryonic stem cells derived from an early human embryo or fetus are capable of unlimited, undifferentiated proliferation in vitro. Renewable tissue cultures of these cells differentiate into a variety of cell types that might be used in transplantation therapy. The principal ethical problem associated with this technique is the short-term culturing of human embryos. Specifically, embryos must be cultured to the blastocyst stage of development (= a pre-implantation or peri-implantation embryo) prior to harvesting ES cells.

Lifting the ban on embryo research will allow scientists to develop new approaches to therapies for heart disease, diabetes, certain central nervous system (CNS) diseases (such as Parkinson's disease), spinal cord injuries, and other organspecific ailments. The rationale behind the ruling is simple enough. Since human ES cells cannot develop into human beings (they can only form organ-specific cells), they should not be considered human embryos.

John Gearhart of Johns Hopkins University obtained human primordial germ (PG) cells from aborted fetuses (5-9 weeks post-fertilisation) and cultured them on mouse fibroblast feeder layers. This source is perfectly legal given the Roe $\mathrm{v}$ Wade decision of 1973. James Thomson of the Univer- sity of Wisconsin isolated human ES cells from surplus human embryos created by in vitro fertilisation for fertility treatment. ${ }^{2}$ A 1994 report of the Human Embryo Research Panel to the director of the National Institute of Health (NIH) ruled that using embryos is acceptable as long as they are not created expressly for research purposes.

Both Gearhart and Thomson characterise their cells as "pluripotent", which means they can be induced to develop into a variety of cell types. The cells might also be "totipotent" (ie, capable of forming any organ tissue of the body), but to determine if they are would require creating chimeras or "patchwork" human beings (= the joining of two zygotes). This involves injecting PG or ES cells into a blastocyst from another conceptus in order to see if the resultant individual demonstrates two genetic lineages.

\section{Some preliminary questions}

Harold E Varmus, the director of NIH, clarified that although it will still be illegal to use federal funds to procure human ES cells in the manner Thomson did, researchers can make use of the cells so obtained. Varmus went on to say: "the prospect of doing amazingly interesting science is really quite wonderful". In answer to that insouciant remark, Richard $M$ Doerflinger, associate director for policy development at the National Conference of Catholic Bishops, suggested that scientists obtain stem cells from spontaneously aborted fetuses rather than destroying viable ones. This intriguing possibility fails to consider other ethical concerns, such as the "commodification" of reproductive materials. David B Resnik argues that gametes and genes may be treated as incomplete commodities (ie, non-human beings), but whole genomes, zygotes and embryos should not be sold on the research market. ${ }^{3}$ Human PG and ES cells fall into the first category, but the mode of their retrieval falls into the second.

Some formidable ethical questions remain amidst the excitement over this new technical breakthrough. Are elective abortion or in vitro fertilisation suitable sources of human PG cells? Is 
the culturing and subsequent destruction of a human blastocyst ethically acceptable?

The ethical ramifications associated with human PG and ES cells research are not taken lightly by Varmus. He said that NIH respects and recognises the many ethical and legal concerns people have about the use of human pluripotent stem cells and the way they are procured. "We are firm in our conviction that federal funds should not be used for this purpose until both the legal concerns and these ethical concerns have been addressed and many constituencies, including congress and the public, have been consulted."

\section{The pros and cons of research with human ES cells}

Evan Y Snyder, an assistant professor of neurology at Children's Hospital and the Harvard Medical School, cloned a human embryonic neural stem (ENS) cell from fetal forebrain. ${ }^{5}$ These cells could be used for therapeutic grafting into adults for the treatment of a variety of inherited neurogenetic defects, including Tay-Sachs disease, birth-related oxygen deprivation, spinal cord injuries, and brain tumours.

Snyder and his co-workers removed cells from deep within the forebrain of an aborted fetus and cloned the ENS cells. They grafted the immature stem cells into different areas of the developing mouse brain, and the ENS cells migrated along existing developmental pathways, maturing into location-specific neural and glial cells. The in-culture-enzyme-producing ENS cells appear to correct the underlying Tay-Sachs deficiency, offering hope that single-gene or multi-gene inherited cerebral disorders might be corrected in this fashion. The work of Snyder's group falls outside the current debate on fetal tissue research, as they were able to perpetuate a single sample of fetal tissue into constantly renewing stable cell lines. ${ }^{6}$ Nevertheless, human ES cells can only be identified and cultured after an embryo has developed for a few cell divisions. A technician must isolate and incubate an embryo prior to removing the pluripotent ES cells from the inner cell mass of the blastocyst.

Arguing that ES cells are not human beings because they cannot develop into adult human beings is probably a correct inference, but is a blastocyst a human being? I contend that it is. After all, it contains a complete genome and all that is needed to develop into an adult human being. The only alternative is to term it cadaveric tissue, ${ }^{7}$ which it certainly is not! Hence, our ethical dilemma is one step removed from the problem of procurement (ie, elective abortions or in vitro fertilisation). What is the ethical justification for sustaining the life of human embryos in vitro for the express purpose of harvesting PG and ES cells?

In the opinion of Arthur Caplan and others (who are reasoning in an exclusively utilitarian way), we have a duty to consider the promise future stem cell therapies offer for those who are paralysed, burned, or dying of liver or pancreatic failure, brain injuries, and other debilitating conditions. In effect, the moral status of embryos must be balanced with the needs of those who are sick, injured or dying. While Caplan rejects the idea of experimenting with embryos for the sake of basic research, "if an embryo already exists, then it seems to me morally acceptable to use it for research since it will never become a human being". 8

I submit that we need a clear definition of the moral and legal status of human embryos and that we should call for a moratorium on human blastocyst research in vitro. This will not be easy to achieve unless we reach a consensus on biological criteria indicative of the sanctity of human life.

\section{Criteria for determining the sacredness of life}

The most significant issue to address in discussions of genetic science is a proper understanding of human nature. ${ }^{9}$ Judaism and Christianity emphasise the unique dignity of human beings created in the image and likeness of God. ${ }^{10}$ The significance of the imago Dei varies somewhat among different religious groups, depending on one's concept of the nature of God and the divine characteristics a human being reflects. One of the more common meanings of this biblical image is intelligence and will. Obviously, an embryo or fetus cannot manifest knowledge or love, and presumably has no innate experience of either. Thus Ronald Dworkin argues that while a fetus should be valued as intrinsically sacred, it does not possess the right to life because the rule of law does not touch upon intrinsic values; these are detached personal beliefs of conscience. ${ }^{11}$

Paul Ramsey warned that in failing to recognise the limits and constraints we must place on scientific inquiry we run the risk of re-enacting Promethean pride and hubris. Once we learn what it means and how it is that we are (or can become) good human beings, we will cease trying to "play God". ${ }^{12}$ Specifically, we will cease trying to define what is right and wrong. Moral knowledge, like all knowledge, is a discovery and not an invention.

On February 22, 1987 the Roman Catholic Church issued an instruction on respect for human life, entitled Donum Vitae. Far from 
censuring the efforts of science and technology in the service of humanity, Donum Vitae discusses biomedical research in light of our God-given dominion over creation. Significantly, the document stresses that "one cannot derive criteria for [ethical] guidance from mere technical efficiency, from research's possible usefulness to some at the expense of others". ${ }^{13}$

\section{Fundamental criteria}

The fundamental criteria for making moral judgments about technical questions in bioethics are the inviolable integrity of each individual human life and the special nature of the transmission of life. The most salient feature of the first criterion is the belief that the human soul is created immediately by God and that the unity of the body/soul composite obviates abuse of the body at any stage of development. "Human life is sacred because from its beginning it involves 'the creative action of God' and it remains forever in a special relationship with the Creator, who is its sole end." 14

While the idea of the soul as the principle of unity is problematic for some, Thomas Aquinas's use of the hylomorphic theory and the primitive state of embryological knowledge at the time made it difficult to explicate human animation and body/soul union. ${ }^{15}$ These limitations should not distract us from an extremely important insight: we can know the truth by participating in the ratio divina. ${ }^{16}$

If we are going to espouse a sanctity of life standard, how do we balance the promised benefit for the sick and disabled with an absolute prohibition against abortion? Don't we compromise this standard by failing to condemn killing in a just war, in self-defence, and in allowing capital punishment? I leave aside the question of the philosophical validity of proportionalism ${ }^{17}$ except to mention that the medical benefits which might accrue for some patients do not outweigh the grave consequences for the embryo that is killed in order to procure ES cells for medical therapy.

While the fifth commandment forbids killing a human being, the state has the right to entrust a soldier with the mission of killing a foreign combatant when just social order is gravely challenged. Similarly, the state can execute a convicted murderer if he or she continues to pose a serious threat to the common good. And if an assaulted party ends the conflict by killing the aggressor in self-defence, that person is not a murderer (assuming he does not directly intend to kill the aggressor but to disable him). Only those who are free of grave injustices against the life of others retain the right to life in the strictest sense, because a defining circumstance of the right to life is innocence. A conceptus is always innocent of wrongdoing, while a person who threatens the life of another ceases to be innocent.

While current debates on life issues focus on the origin of life, we might also consider our ultimate destiny. Brian V Johnstone for one argues that the resurrection should have a central place in Christian ethics. ${ }^{18}$ Paul's lapidary statement is just as shocking today as it was centuries ago: "If Christ has not been raised, then our preaching is in vain and your faith is vain". ${ }^{19}$

The expression "resurrectio huius carnis" appears in over 20 symbols and creeds dating from 370-1336 CE, stressing the resurrection of this body. ${ }^{20}$ The earliest sure reference to a bodily resurrection in Hebrew scripture is Daniel 12:1-3 (ca $168 \mathrm{BCE}$ ), which became the central image of the liturgy of Rosh Hashanah. "Many of those who sleep in the dust of the earth shall awake, some to everlasting life, and some to shame and everlasting contempt". ${ }^{21}$ This revolutionary idea moved Jewish thought beyond a carpe diem attitude ${ }^{22}$ to embrace a compassionate God who raises both the righteous and the evil in order to give them their just reward. ${ }^{23}$

\section{The ethical debate on abortion and in vitro fertilisation}

Abortion is a challenging issue for Christians because there are no explicit New Testament texts concerning it, and in vitro fertilisation is even more difficult to address from a scriptural point of view.

One of the biblical passages commonly cited in favour of protecting life in the womb is Psalm 139:13-16. ${ }^{24}$ This passage and others like it (for example Jeremiah, 1:5) $)^{24}$ are poetic affirmations of the loving omniscience and foreknowledge of God, not direct claims that the human fetus is a person. None the less, the larger context of the symbolic world of Scripture does offer implicit paradigms for elucidating a proper evaluation of the ethical status of a fetus. The most compelling metaphorical correlation is Jesus' parable of the Good Samaritan. ${ }^{25}$ Jesus, by answering the self-justifying question of the lawyer: "Who is my neighbour?", "rejects casuistic attempts to circumscribe our moral concern by defining the other as belonging to a category outside the scope of our obligation". ${ }^{26}$ We have a duty to respect all human life, whether it is clearly seen as personal or not.

Given the paucity of scriptural evidence directly addressing abortion, other forms of argument are usually adduced such as reason and experience. 
Although there are problems discussing this issue in terms of rights, the sacredness of life, or quality of life, clarifying our concept of rights can advance discussion of this issue (as well as others). ${ }^{27}$ The principal right we need to address is the right to life of all conceived human life, even a blastocyst.

\section{Multipotent precursor cells and transplantation}

Evan Snyder's research group has demonstrated that degenerating adult murine neocortical cells induce transplanted multipotent neural precursor cells to differentiate into neurons and glial tissue. ${ }^{28}$ Another group has shown that xenotransplantation and stem cell transplantation effectively restores the damaged circuitry of porcine dopaminergic neurons in Parkinson's disease. ${ }^{29}$

The adult human brain has a very limited ability for self-repair, and that is especially true of neurons; nevertheless, neural stem cells can serve as self-renewing precursors of neurons and glia. Interestingly, these cells have been isolated from both the embryonic and adult mammalian CNS; and there may be latent CNS neuroepithelial stem cells in the adult brain (for example, in the basal ganglia). ${ }^{30} \mathrm{D} \mathrm{W}$ Pincus has harvested neuronal and oligodendroglial precusors from the adult human brain and clonally expanded them in tissue culture to provide a renewable supply of cells for transplantation. ${ }^{31}$ These progenitors can be genetically manipulated to express exogenous genes for neurotransmitters, neurotrophic factors, and metabolic enzymes. ${ }^{32}$

If a sufficient pool of NES cells is found, they could be used to "reseed" damaged portions of the brain, restoring the functional integrity of large-scale defects due to stroke or multi-infarct dementia, as well as multifocal diseases such as multiple sclerosis. Several years ago I discussed the theoretical possibility of using autografts of progenitor cells to induce the regeneration of damaged tissue. ${ }^{33}$ This technique is of interest because allografts of fetal tissue are subject to immunorejection $^{34}$ and they can carry infections and pathological abnormalities. ${ }^{35}$

Of equal importance to successful transplantation is the supporting connective tissue matrix. Even adult cells retain responsiveness to their surrounding connective tissue environment. ${ }^{36}$ Identifying and characterising the controlling substances of cell differentiation, such as growth factors and morphogenetic proteins, ${ }^{37}$ may afford a good alternative source to fetal tissue.

\section{Conclusion}

Obtaining human PG and ES cells from aborted fetuses or surplus embryos of in vitro fertilisation are unacceptable from an ethical standpoint. Another possible source is spontaneous, nonelective abortions, but that solution does not address the question of embryo manipulation. I discuss the possibility of using adult autologous PG and ES cells to avoid the destruction of human embryos. Transplantation techniques using connective-tissue inducing proteins may be more effective than using PG and ES cells alone.

The Rev fohn R Meyer, MS, STD, is a priest of the Opus Dei Prelature, currently living in the Archdiocese of San Francisco, California, USA.

\section{References and notes}

1 Shamblott MJ, Axelman J, Wang S, Bugg EM, Littlefield JW, Donovan PJ, et al. Derivation of pluripotent stem cells from cultured human primordial germ cells. Proceedings of the National Academy of Sciences 1998;95:13726-31.

2 Thomson JA, Itskovitz-Eldor J, Shapiro SS, Waknitz MA, Thomson JA, Itskovitz-Eldor J, Shapiro SS, Waknitz MA,
Swiergiel JJ, Marshall VS, et al. Embryonic stem cell lines derived from human blastocysts. Science 1998;282:1 145-7.

3 Resnik D. The commodification of human reproductive mate3 Resnik D. The commodification of human reprod

4 XxxxxxxxThe Washington Post 1999 Jan 27: A 20.

5 Flax JD, Aurora S, Yang C, Simonin C, Wills AM, Billinghurst LL, et al. Engraftable human neural stem cells respond to developmental cues, replace neurons, and express foreign genes. Nature and Biotechnology 1998;16:1033-39; Whittemore SR, Snyder EY. Physiological relevance and functional potential of central nervous system-derived cell lines. Molecular Neurobiology 1996;12:13-38.

6 Snyder presented this work at the American Association for the Advancement of Science in Anaheim, California on January 15, 1999. The presentation was entitled Neural stem cells: . The presentation was entited $\mathrm{N}$ strategies.

7 Turner DA, Kearney W. Scientific and ethical concerns in neural fetal tissue transplantation. Neurosurgery 1993;33:1033.

8 Caplan A. Stem cell therapy raises ethical issues: should human 8 Caplan A. Stem cell therapy raises ethical issues: should human

9 Gustafson JM. Where theologians and geneticists meet. Dialog 1994;33:7-16.

10 Holy Bible. Genesis I, 26-27.

11 Dworkin R. Life's dominion: an argument about abortion, euthanasia, and individual freedom. New York: Knopf, 1993.

2 Ramsey P. Fabricated man: the ethics of genetic control. New Haven: Yale University Press, 1970.

13 Congregation for the Doctrine of the Faith. Donum vitae 2.2. Boston: St Paul Editions, 1987: 7.

14 See reference 13: 5.2 .

15 Farmer L. Human is generated by human and created by God. Catholic Philosophical Quarterly 1996;70:413-27.

16 Aquinas T. Summa theologiae I-II, q 19, a 4.

17 Finnis J. Moral absolutes: tradition, revision, and truth. Winnis J. Moral absolutes: tradition, revision, and truth.

18 Johnstone BV. Transformation ethics: the moral implications of the resurrection. In: Davis ST, Kendall D, O'Collins G, eds. the resurrection: an interdisciplinary symposium on the resurrection of fesus. Oxford: Oxford University Press, 1997: 339-61.

9 Hof Hesus. Oxford: Oxford University

20 O'Callaghan P. La fórmula «resurrección de la carne» y su significado para la moral cristiana. Scripta Theológica 1989;21: 777-803.

21 Holy Bible. Daniel, xii:1-3; Daniel, xii: 2

22 Holy Bible. Ecclesiastes, iii: 16-21.

23 Segal AF. Life after death: the social sources. In: Davis ST, Kendall D, O'Collins G, eds. The resurrection: an interdisciplinary symposium on the resurrect

24 Holy Bible. Psalm 139: 13-16; Jeremiah, i:5.

25 Holy Bible. Luke, x: 25-37.

Hays RB. The moral vision of the new testament: a contemporary introduction to new testament ethics. San Francisco: HarperCollins, 1996:451 
27 Meyer JR. Natural rights, fact or fiction? Human rights and 'the risk of freedom'. Scottish Fournal of Theology 1999;52:47-81.

28 Snyder EY, Yoon C, Flax JD, Macklis JD. Multipotent neura precursors can differentiate toward replacement of neurons undergoing targeted apoptotic degeneration in adult mouse neocortex. Proceedings of the National Academy of Sciences 1997 94:11663-8.

29 Jones DG, Redpath CM. Regeneration in the central nervous system: pharmacological intervention, xenotransplantation, and stem cell transplantation. Clinical Anatomy 1998;11:26370 .

30 Cattaneo E, McKay R. Identifying and manipulating neuronal stem cells. Trends in Neuroscience 1991;14:338-40.

31 Pincus DW, Goodman RR, Fraser RA, Nedergaard $M$, Goldman SA. Neural stem and progenitor cells: a strategy for gene therapy and brain repair. Neurosurgery 1998;42:858-67.

32 Rao MS, Anderson DJ. Immortalization and controlled in vitro differentiation of murine multipotent neural crest stem cells. Fournal of Neurobiology 1997;32:722-46; Morshead CM, Craig CG, van der Kooy D. In vivo clonal analyses reveal the proper- ties of endogenous neural stem cell proliferation in the adult mammalian forebrain. Development 1998;125:2251-61.

33 Meyer JR. The regenerative potential of the periodontal ligament. Fournal of Prosthetic Dentistry 1986;55:260-5.

34 Stein DG, Glasier MM. Some practical and theoretical issues concerning fetal brain tissue grafts as therapy for brain dysfunctions. Behavioral and Brain Sciences 1995;18:36-45.

35 Brundin P, Bjorklund A, Lindvall O. Practical aspects of the use of human fetal brain tissue for intracerebral grafting. Progress in Brain Research 1990;82:707-14.

36 Hayashi N, Cunha GR, Parker M. Permissive and instructive induction of adult rodent prostatic epithelium by heterotypic urogenital sinus mesenchyme. Epithelial Cell Biology 1993;2:6678 .

37 Mujtaba T, Mayer-Proschel M, Rao MA. A common neural progenitor for the CNS and PNS. Developmental Biology 1998;
200:1-15; Kinbara H, Cunha GR, Boutin E, Hayashi N, Kawa200:1-15, Kinbara H, Cunha GR, Boutin E, Hayashi N, Kawamura J. Evidence of stem cells in the adult prostatic epithelium based upon responsiveness to mesenchymal inductors. Prostate 1996;29:107-16.

\section{News and notes \\ Human Rights in Medicine}

An international summer course on health care ethics, Human Rights in Medicine, will be held from June 26-30 2000 in Dubrovnik, Croatia. The course offers the opportunity for participants to explore the challenging ethical dilemmas in the provision of health care as well as the broader implications of human rights for health policy and health care systems in transition. For further information please contact: Miroslav Mastilica, 'Andrija Stampar' School of Public Health, University of Zagreb, Rockefellerova 4, HR-10000, Zagreb, Croatia. Telephone: +3851468 4440; fax: +3851468 4441; email: mmastil@andrija.snz.hr

\section{News and notes \\ Ethics and genetics}

An Advanced Europen Bioethics Course, Ethics and Genetics, will be held from 16-18 November 2000 in Nijmegen, the Netherlands. Specialists from various countries will discuss, for example, ethics and the Human Genome Project; genetic counselling; genetic screening; human gene therapy, and geneticisation. All lectures and plenary sessions will be held in English. The course fee is Dfl 650. For further information please contact: $N$ Steinkamp, Catholic University Nijmegen, 232 Dept of Ethics, Philosophy and History of Medicine, PO Box 9101, 6500 HB Nijmegen, Netherlands. Telephone: 003124 3615320; fax: 003124 3540254; email: n.steinkamp@efg.kun.nl 